\title{
Improving the Speaking Skill of Primary School Students Instructed in a Multigrade Class through Cartoons
}

\author{
Ceren Duran \\ Primary School Teacher, The Ministry of Education, Kahramanmaraş, Turkey \\ ORCID: 0000-0002-0102-3461
}

\author{
Emel Güvey Aktay * \\ Department of Primary Education, Muğla Sitkı Koçman University, Muğla, Turkey \\ ORCID: 0000-0002-5659-8924
}

\author{
Oğuzhan Kuru \\ Department of Primary Education, Kahramanmaraş Sütçü İmam University, \\ Kahramanmaraş, Turkey \\ ORCID: 0000-0002-1772-4406
}

Article history

Received:

13.11.2020

Received in revised form: 07.02.2021

Accepted:

13.03.2021

Key words:

Speaking skill,

Speech errors,

Cartoons
In the current study, it is aimed to improve the speaking skill of primary school students instructed in a multigrade class through cartoons. The current study employed the action research design. Participants of the study are 3rd and 4th grade primary school students instructed in a multigrade class in a village school in the city of Kahramanmaras in Turkey in the 2019-2020 school year. The data in the study were collected through observations, interviews and documents. A program consisting of 7 applications in which cartoons are used for students with speech problems was prepared and applied within the scope of the language teaching course. The application continued for four weeks until the students' speech problems were reduced to a certain level and they achieved some improvement in speaking. Plans were prepared every week in line with the opinions of the field experts and the development status of the students in speech was evaluated. At the end of the study, the students' opinions about the application were taken through semistructured interviews. At the end of the study, it was observed that the speech errors of the students decreased. At the same time, it was determined that there was an increase in the speaking time of the students and the number of words and sentences they used. The most important and positive change occurred in the psychological dimension of speech. Students' motivation increased and they started to behave more comfortably when speaking. In this direction, their anxiety decreased and their desire to speak increased. Furthermore, positive changes occurred in the students' adjustment of their tones and sound intensities. The words spoken by the students became more comprehensible.

\footnotetext{
*Correspondency: emelguveyaktay@mu.edu.tr
} 


\section{Introduction}

Language is one of the most important tools used in communication. People can convey their feelings, thoughts and beliefs through language (Demirel \& Şahinel, 2006). Speaking is one of the most important language skills for individuals to express themselves properly in social life. Speaking, which effects success or failure in school, family, work and community life, can play a very important place in the social and interpersonal interactions (Erdem \& Deniz, 2008; Temizkan, 2009). Children and adults use speaking skill more than the other language skills. The acquisition of speaking, one of the expression skills and the acquisition of listening as one of the comprehension skills, occur earlier than the other language skills. The child comes to school having already mastered listening and speaking skills to a certain extent (Tompkins, 1998). Speech acquired through informal education is not at a sufficient level for effective use. It is possible to have students reach a more active level of using speaking skill with the education provided in schools (Demir, 2010). With the start of the school, the acquisition of the language skills that students have randomly developed up to that time should be addressed in a planned way and attention should be paid to language teaching. At schools, language teaching should be systematic and given correctly and effectively, with the grace and beauties of the language (Sever, 1993). Correct and effective speaking skills can be developed through school-type learning and individual efforts (Sever, 2011).

Turkish, which is one of the mother tongue teaching courses in primary school, has important functions in terms of students' establishing healthy relationships with the society they live in, understanding what is happening around them, and conveying what they understand verbally and in writing (Doğan, 2009). In the literature, there are studies conducted with students of different grade levels on the improvement of speaking skill in language teaching lessons (Bashir, Azeem \& Dogar, 2011; Boonkit, 2010; Eryılmaz, 2015; Kuru, 2013; Oradee, 2012; Temizyürek, 2007).

Each individual's language learning process is unique. For this reason, various methods, approaches and techniques should be used while imparting language skills to students (Akyol, 2011). In order to motivate students and enrich the content of lessons, it is necessary to draw on different approaches and teaching methods. Teaching with cartoons is one of these approaches. Teaching with cartoons can be used to attract attention, to help students concentrate and to motivate them and as the first step of the act of teaching in education (Stevenage, 1995; as cited in Üner, 2009).

Children are interested in painting from an early age and learn the alphabet through painting in the reading age. Every child loves painting, and painting is seen as a means for children to express themselves. Therefore, children are interested in cartoon, which is a simple and effective communication tool in school age (Dönmez, 2013). Cartoon, which is an art of drawing that includes critical and important writings (Perkins, 1975), helps students gain the skills of dreaming, thinking, controlling their emotions and being sensitive through their aesthetic aspects (Çer, 2017). Students' motivation and participation increase, and students understand the subjects taught in lessons better using pictures and cartoons (Örs, 2005). In addition to the studies in which cartoons are used in language teaching (Akgül, 2019; Akkaya, 2011; Bayülgen, 2011; Dönmez, 2013; Soy, 2019; Tsou, 2005), there are also studies in different disciplines. There are studies using cartoons with students of different grade levels in the field of science teaching (Clary \& Wandersee, 2010; Keogh \& Naylor, 1999; Orhan, 2018; Stephenson \& Warwick, 2002; Şenocak, 2018) and social studies teaching (Akengin \& İbrahimoğlu, 2010; Koçoğlu, 2012; Oban, 2017). 
Cartoons are one of the important tools used to improve speaking skills (Şahan, 2009). In addition, cartoons are an effective instructional tool for the achievement of objectives such as comprehension, written and verbal expression and students' being able to express their thoughts on a subject in Turkish lessons (Dönmez, 2013). Given the importance of speech and cartoons for students, it is surprising that there are few studies on the use of speech and cartoons at primary school level. Speaking training should be given to individuals from an early age/ at a young age in order for effective and beautiful speech to occur.

In this connection, the purpose of the current study is to determine how the Turkish speaking skill of primary school students taught in a multigrade class can be improved through cartoons. Multigrade classes are usually seen in regions where schools are scattered and inaccessible because of the low population density in the region (Little, 2001) or in places where the number of teachers and classes is inadequate (Köksal, 2002). In line with this purpose, the subjects of how the process of speaking skill development works, how cartoons contribute to speaking skill and what the students' opinions about the use of cartoons to develop speaking skill are have been addressed.

\section{Method}

The current study employed the action research design, one of the qualitative research designs. Action research is defined as the process of studying the real classroom or school situation to understand and improve the quality of actions and teaching (Hensen, 1996; McTaggart, 1997; Schmuck, 1997; as cited in Johnson, 2005). Action research is a systematic process for solving problems or developing the existing practices in the field of education (Tomal, 2010).

The researcher is a class teacher. She conducted the study on the students she was teaching. The researcher observed the students in the class for a term and recognized that they made some speaking mistakes. The main speaking problems observed in the students were related to the use of local dialects and faltering. This was considered as a problem for the researcher to solve in her class and the research process was initiated in the second term. Prior to the research, the researcher had her students watch an animated film that she thought to be enjoyable for the students to watch. By asking questions about the animated film, she talked to the students for a while and the researcher's observations were recorded through the Speech Disorder Observation Form. Thus, the problems experienced by each student in speaking were determined according to certain criteria.

\section{Participants}

The study group of the current research is comprised of 9 students taught in a multigrade class of a village school in the city of Kahramanmaraş in Turkey in the 2019-2020 school year. Three of the students are 3rd graders and 6 of them are 4th graders. The students are living in a village. Although the distance between home and school is long, they go to the school on foot. Most of the families of the students make their living from agriculture. Their mothers are illiterate. The students work in fields after the school. This can also affect some students' attendance to the school. In the selection of the participants, the criterion sampling method, one of the purposive sampling methods, was used. Criterion sampling requires the selection of the cases that meet some predetermined criteria (Patton, 2002). In this context, as all the students in the classroom spoke in their local dialect (meaning local accent, local words), it was assumed that the speaking skill of all the students should be developed. Information about the participating students is given in Table 1. 
Table 1. Personal information about the students

\begin{tabular}{lllllllc}
\hline $\begin{array}{l}\text { Student } \\
\text { No }\end{array}$ & $\begin{array}{l}\text { Student } \\
\text { (Code) }\end{array}$ & $\begin{array}{l}\text { Grade } \\
\text { Level }\end{array}$ & Age & $\begin{array}{l}\text { Father's } \\
\text { Job }\end{array}$ & $\begin{array}{l}\text { Mother's } \\
\text { Job }\end{array}$ & $\begin{array}{l}\text { The } \\
\text { Number of } \\
\text { Siblings }\end{array}$ & $\begin{array}{l}\text { Any } \\
\text { Disorder }\end{array}$ \\
\hline 1 & S1 & 4 & 10 & Farmer & Housewife & 3 & No \\
2 & S2 & 4 & 10 & Farmer & Housewife & 8 & No \\
3 & S3 & 4 & 10 & Farmer & Housewife & 3 & No \\
4 & S4 & 3 & 9 & Farmer & Housewife & 3 & No \\
5 & S5 & 4 & 10 & Farmer & Housewife & 9 & Lo \\
6 & S6 & 4 & 10 & Farmer & Housewife & 4 & No \\
7 & S7 & 3 & 9 & Farmer & Housewife & 2 & No \\
8 & S8 & 4 & 10 & Farmer & Housewife & 4 & No \\
9 & S9 & 3 & 9 & Mechanic & Housewife & 2 & \\
\hline
\end{tabular}

As a result of the classroom observations made by 3 classroom teachers, interviews with the parents and examining the student files of the 9 students, it was concluded that none of the students had been diagnosed with physical, psychological or mental disability, and 1 student had lisping.

\section{Data Collection}

Prior to the research process, the researcher obtained the necessary permissions from the Ministry of National Education and held a meeting with the parents of the students. In the meeting held with the parents in the classroom, the researcher informed the parents about the study. Different data collection tools were used in the current study including the personal information form, the speech disorder form used to analyse the observation data consisted of video recordings, the researcher's diary having the observations related to the process apart from the researcher's observation data, the expert opinion form used by experts to evaluate the weekly observation data, semi-structured interviews conducted with the students and the cartoons used in the activities.

In order to get observation data, The Speech Disorder Observation Form was used. The Speech Disorder Observation Form prepared by Kuru (2013) is a form consisting of 30 items in total and grouped under four headings as 'psychological (4 items)', 'physical (11 items)', 'grammar and spelling related to speech (12 items)' and 'topic (3 items)'. In the form, the frequency of exhibiting a speech behaviour is indicated by marking one of the following response options: 'never, rarely, sometimes, often, usually and always'.

The researcher planned to use cartoons in speech activities thinking that they would make speech more visual and comfortable for the students appealing to more sensory organs. In the selection of the cartoons, attention was paid for them to be related to up-to-date subjects to be understood and interpreted by primary school students. Speaking activities with cartoons were carried out within the scope of mother tongue (Turkish) teaching lessons.

\section{Data Analysis}

In the analysis of the collected data, the qualitative data analysis technique was used. In this regard, the data were analyzed by using descriptive analysis. In descriptive analysis, the collected data are summarized and interpreted according to the pre-determined themes (Yıldırım and Şimşek, 2018).

Macro and micro analyses were made by transcribing the speeches in the video recordings. The data obtained during the research process were shown to the experts in the validity committee every week and the experts were asked to convey their observations to the Speech 
Disorder Observation Form. The weekly progress of each student was followed by taking the average of the responses given by two experts to the form besides the researcher. The analysis of the research data was carried out on the basis of the headings in the Speech Disorder Observation Form. In addition, the data obtained from the video recordings were divided into themes and sub-themes in line with the research questions and the situations that emerged outside the observation form were determined. The researcher diary and student opinions were also used as supportive data sources. After the semi-structured interviews with the students were written down, the data obtained were analyzed based on the topics asked in the interview and using descriptive analysis. The data obtained from the semi-structured interviews conducted with the students are presented in the form of themes and sub-themes.

In qualitative research, validity and reliability are discussed under the headings of credibility, transferability, dependability and confirmability (Guba, 1981). Within the scope of the credibility of the current study, the researcher interacted with the students during a whole term and thus conducted the research in a long period covering a term. Since the researcher was the classroom teacher of the students, she had the opportunity to closely observe both their social life and classroom behaviours and was in close interaction with them. Within the context of expert review and diversification (Erlandson et al., as cited in Yıldırım \& Şimşek, 2018), another dimension of credibility, the researcher informed field experts about the research process and received their opinions in the validity committees. In the data collection process, various data collection sources were used by making use of interviews and documents (researcher diary, cartoons) as well as video recordings.

\section{Research Process}

The stages of the research process are given in Figure 1. The activities conducted every week during the research process were carried out within the action research cycle. The plans were implemented in the form of another action plan in line with the opinions of the validity committee.

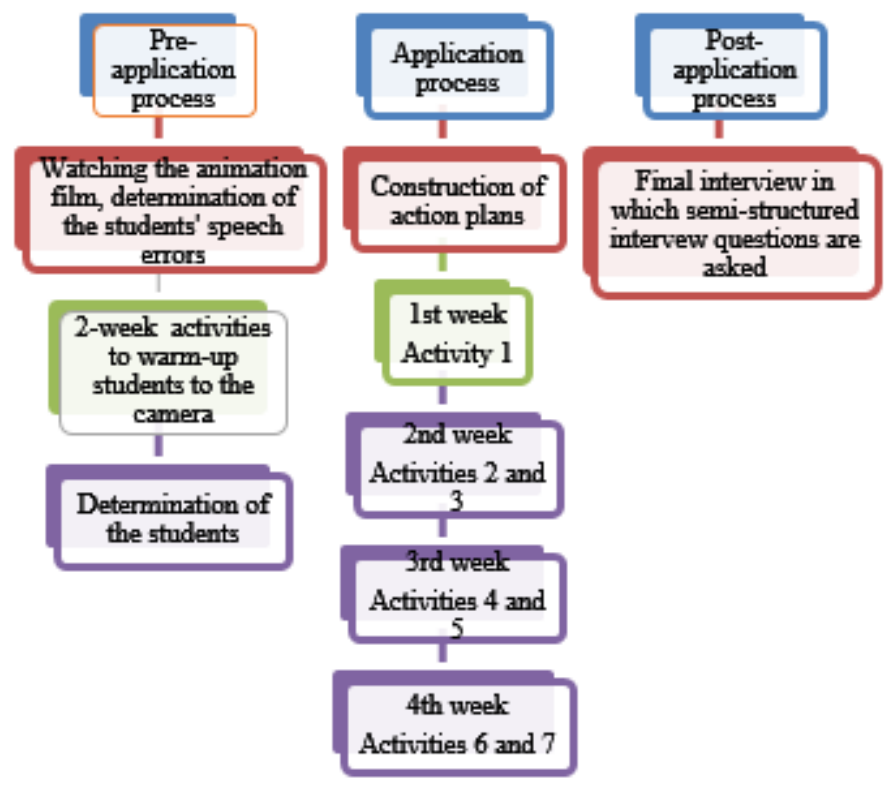

Figure 1. The stages of the action research followed in the research process

The researcher observed the students' behaviours while they were watching animated films and took notes about her observations. The researcher collected data about the general 
behaviours of the students by taking such notes as the following: "The students watched the movie with laughter from the first scene. They tried to satisfy their curiosity by asking questions. They watched the movie with interest and attention." (Researcher's Diary, 01/10/2020). "I observe that the 3rd class students are distracted from time to time. Especially S4 is very distracted. He walks around in the classroom." (Researcher Diary, 01/10/2020). "S1 shortly examined the camera. S1 continued to look at the camera from time to time." (Researcher's Diary, 02/13/2020).

The research was carried out by using 7 applications for 4 weeks and 14 hours in total within the context of Turkish lessons. In the current study, 6 cartoons were used in the activities conducted to develop the speaking skill of the students. A great care was taken for selecting cartoons suitable for the students' level and for the students to talk about them comfortably. The cartoons were distributed to each student as colour printouts and a copy of each cartoon was hung on the classroom board.

In the first week, the students were seated in a circle and were asked what they thought about the award-winning cartoon (K1), which tells that TV addiction turns people into puppets. In addition, the students were asked follow-up questions to encourage them to talk more. These questions are about what students see in the cartoons, what the cartoons tell, and the message they want to convey.

The second week was planned in two sessions. In the first session, the students were seated in desks arranged in a raw with pairs in each desk. A cartoon (K2) showing the consequences of the damages given to the nature was demonstrated to the students. The students were asked to discuss the measures to be taken to prevent the damages given to the nature. Each student spoke individually for three minutes after having discussed the topic with their group mates. In the other session of the second week, a cartoon (K3) was chosen that depicts the difference between disabled people and other people who create obstacles for these people. The opinions of each student about the cartoon were asked. In this process, the students were encouraged to talk with the questions directed by the researcher.

In the activity in the third week, a cartoon (K4) describing how reading a book enlightens people was examined. After receiving each student's comments about the cartoon, groups of two were formed. The students were asked to create role plays about what the characters in the cartoon might be talking about.

In the fourth week, a cartoon (K5) about aquatic organisms affected by drought was selected. The students were asked to express their thoughts on the cartoon and each student was given the right to speak. A cartoon (K6) about overcoming obstacles was chosen in the next session. After the students talked about this cartoon, the students were asked to create and tell a story in a collaborative fashion by each student's adding a sentence to the story. Examples of cartoons are given in Picture 1 and Picture 2. 


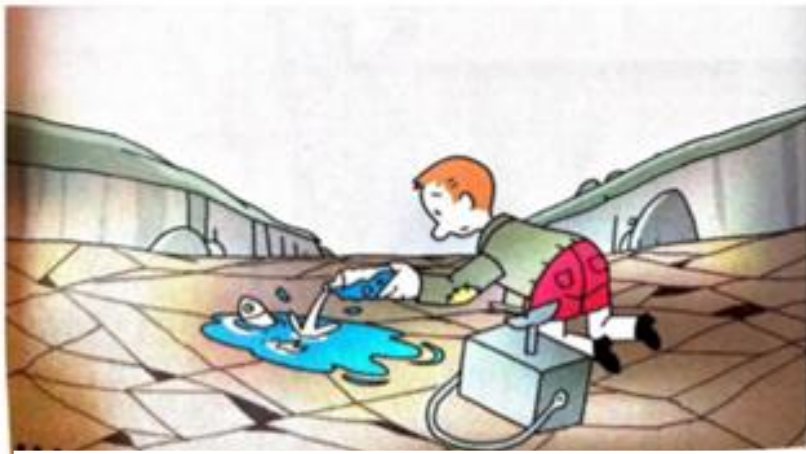

Picture 1. Cartoon 5

Source: Demirci, H. (2016) The world with lines. Izmir: Desen Publishing. (as cited in Çer, 2017).

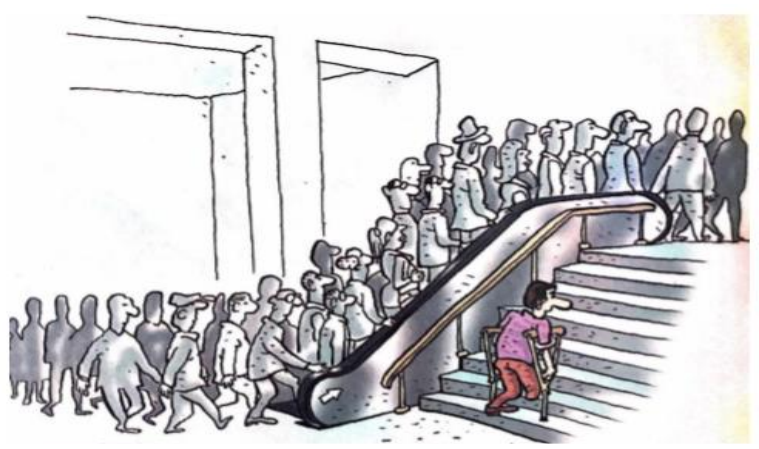

Picture 2. Cartoon 3

Source: Güzeloğlu, C. (2010). The exhibition with the theme of being disabled in the city of civilization (As cited in Çer, 2017).

After the applications, semi-structured interviews were conducted with the students. In the interviews, the opinions of the students on speaking activities with cartoons and their use in daily life were discussed.

\section{Findings}

Findings regarding the research process and how the cartoons improved the students' speaking skill in this process are given here. In the study, the findings regarding the changes in the speaking skill of the students during the process are described by considering their weekly development and 4 dimensions (psychological, physical, grammar and topic) in the Speech Observation Form. The speaking status of the students before the application was compared with their speaking status determined after the application. Weekly progress of the students in speaking is presented by comparing each week with the previous week.

\section{Weekly changes occurring in the psychological dimension in the students}

When the activities carried out in the first week were evaluated in terms of the psychological dimension, it was seen that while 3 students changed positively or remained stable according to the preliminary interviews, a negative change occurred in the speaking status of 6 students. At the end of the second week, 6 students were found to have regressed in the psychological dimension. The most common mistakes committed by 3 students in this dimension were found to be "not reflecting their feelings as much as in the preliminary interviews" and "feeling more uncomfortable when someone is listening to them".

As a result of the activities performed in the third week, 4 students were found to have regressed. The most common speech mistakes were found to be "being disturbed by someone listening to him/her" in 2 students, "increased anxiety " in 1 student, "exhibiting less reflective behaviours" in 1 student, and "decreased willingness to speak" in 1 student. In the fourth week, quite a lot of positive changes were observed in all the students (9). Compared to the previous weeks, only in two of the speech items, regression was observed in one student and these items are "regression in the reflection of feelings" and "feeling uncomfortable while someone is listening to him/her". The other 8 students showed a positive change in all the items in the psychological dimension. In Table 2, the developmental status of the students in speech in terms of the psychological dimension before and after the application is given. 
Table 2. The developmental status of the students in the psychological dimension Item PSYCHOLOGICAL

\begin{tabular}{|c|c|c|c|c|c|c|c|c|}
\hline 1 & $\mathrm{~S} 2$ & S3 & $\mathrm{S} 4$ & S5 & S6 & S7 & S8 & S9 \\
\hline 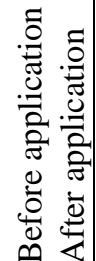 & 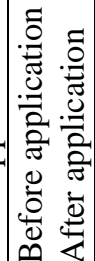 & 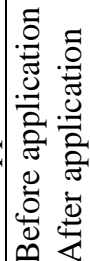 & 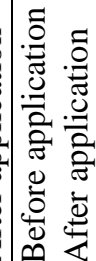 & 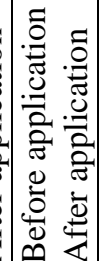 & 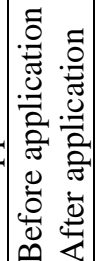 & 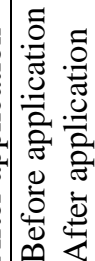 & 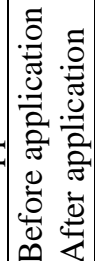 & 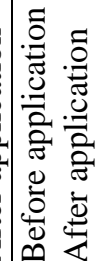 \\
\hline
\end{tabular}

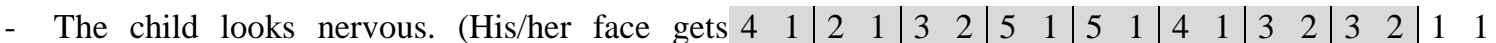
blushed, his/her breathing accelerates, etc....)

+ The child reflects his/her emotions.

+ The child seems willing to talk.

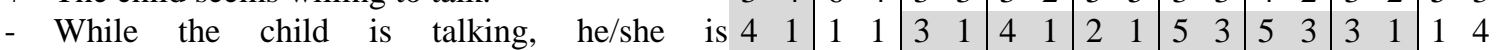
uncomfortable with someone listening to him/her (He/she gets hoarse, does not complete sentences, etc.).

1-Never 2-Rarely 3-Sometimes 4-Often 5-Usually 6-Always

Negative characteristics related to speaking + Desired characteristics related to speaking Characteristics developed in speaking

In the psychological dimension where there are 4 items, the student who showed the most improvement was S1. S1 showed improvement in all the items in the psychological dimension, followed by S3, S5 and S8 showing improvement in 3 items in the psychological dimension. They are followed by S4, S6 and S7 showing improvement in 2 of the items. Of the students showing the least improvement, S2 showed improvement in 1 item and S9 in none of the items. Within the psychological dimension, the highest number of the students showed improvement in the items "being anxious" ( 8 students) and "feeling uncomfortable while someone is listening to him/her" (7 students).

\section{Weekly changes occurring in the physical dimension in the students}

In the physical dimension, a positive change occurred in the students in general or they remained stable compared to their state in the preliminary interviews. The items in which regression was observed compared to their state in the preliminary interviews in the first week were found to be "swallowing words", "monotonous speech", "not making eye contact", "not sitting correctly", "not being able to adjust the intensity of the voice", "comprehensiveness when speaking", "exhibiting unnecessary gestures", "not adjusting the tone of the voice according to the content of the speech" and "not using gestures and mimics correctly". According to their status in the preliminary interviews, there are 3 students who swallowed words more. There is 1 student whose monotonous speaking style increased, 2 students whose voice intensity and audibility decreased, and 2 students whose speech was less comprehensible. The number of the students who used unnecessary gestures more was found to be 4 , the number of the students who adopted a worse seating position while speaking and the number of the students who could not adjust the tone of voice according to the content of the speech was found to be 1 .

In the second week, either positive changes occurred in this dimension or students' performance remained stable. The most common speech mistakes committed by the students in this week were found to be swallowing words, sentence repetition, answering questions with sentence repetitions, monotonous speech and decreased audibility and comprehensibility. A total of 6 students were found to exhibit the act of swallowing words. Compared to the 
preliminary interviews, 1 student was found to make more sentence repetitions, 2 students were found to speak more monotonously, 1 student was found to have decreased his/her audibility and tone of voice and 1 student was found to be speaking less comprehensibly. In the third week, 4 students showed a positive change in the physical dimension. The items in which regression was observed were identified to be not using gestures and mimics correctly, swallowing words, exhibiting unnecessary gestures, and decreased comprehensibility when speaking. In the fourth week, 2 students made less eye contact in this dimension. Two students experienced a decrease in using gestures and mimics, 1 student demonstrated more unnecessary gestures, and 1 student exhibited worse performance in adjusting the tone and audibility of his/her voice. Four students exhibited positive changes in all the items in the physical dimension or their status remained stable. In Table 3, the developmental status of the students in speech in terms of the physical dimension before and after the application is given.

Table 3. The developmental status of the students in the physical dimension

\begin{tabular}{|c|c|c|c|c|c|c|c|c|c|c|c|}
\hline & Item PHYSICAL & S1 & S2 & S3 & S4 & S5 & S6 & S7 & S8 & S9 & \\
\hline & & 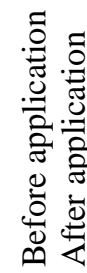 & 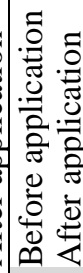 & 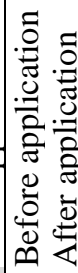 & 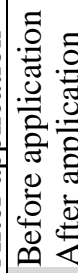 & 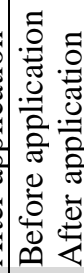 & 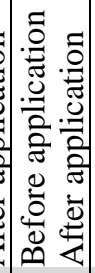 & 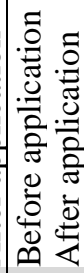 & 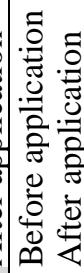 & & 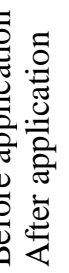 \\
\hline+ & The child makes eye contact with the listener. & 43 & 35 & 54 & 35 & 25 & 24 & 25 & 21 & 3 & 3 \\
\hline+ & $\begin{array}{l}\text { The child is sitting properly (Standing facing the } \\
\text { speaker, sitting at the desk etc.). }\end{array}$ & e6 4 & 65 & 54 & 55 & 45 & $5 \quad 4$ & 35 & 43 & 3 & 4 \\
\hline- & $\begin{array}{l}\text { The child exhibits unnecessary gestures that do not } \\
\text { contribute to speech. }\end{array}$ & t2 1 & 21 & 21 & 21 & 11 & 32 & 13 & 23 & 1 & 3 \\
\hline+ & $\begin{array}{l}\text { The child uses gestures and mimics properly while } \\
\text { speaking. }\end{array}$ & e 2 & 55 & 33 & 32 & & $3 \quad 3$ & 22 & 22 & 2 & 3 \\
\hline+ & $\begin{array}{l}\text { The child adjusts his/her tone of voice according to } \\
\text { the content of the speech. }\end{array}$ & 025 & 45 & 23 & 23 & 25 & & 25 & 22 & 3 & 4 \\
\hline+ & $\begin{array}{l}\text { The child adjusts the intensity and audibility of } \\
\text { his/her voice. }\end{array}$ & f4 5 & & & & 45 & 23 & 25 & & 4 & 4 \\
\hline- & While the child is speaking, his/her voice trembles & 21 & 11 & 21 & 41 & 11 & 3 & 21 & 11 & 1 & 1 \\
\hline+ & $\begin{array}{l}\text { While the child is speaking, he/she can be } \\
\text { understood (He/she does not swallow sounds, does } \\
\text { not add extra syllables). }\end{array}$ & & 44 & 44 & 34 & 44 & 23 & 54 & 42 & 5 & 4 \\
\hline- & While speaking, the child swallows words. & 21 & 22 & 41 & 41 & 12 & 43 & 31 & 33 & 2 & 1 \\
\hline- & $\begin{array}{l}\text { The child starts and finishes the sentence with the } \\
\text { same tone of voice (Monotonous speech). }\end{array}$ & 53 & 33 & $\begin{array}{ll}5 & 3\end{array}$ & 22 & $\begin{array}{ll}5 & 3\end{array}$ & $\begin{array}{ll}4 & 4\end{array}$ & 52 & 45 & 4 & 2 \\
\hline- & $\begin{array}{l}\text { While speaking, the child takes longer gulps } \\
\text { (That causes gaps negatively affecting fluency). }\end{array}$ & 21 & 21 & 51 & 21 & 41 & $1 \quad 1$ & 21 & 21 & 2 & 1 \\
\hline
\end{tabular}

The student who showed the most improvement in the physical dimension consisted of 11 items was found to be S4 (9 items), followed by S1 and S7 (8 items). While S5 and S6 demonstrated improvement in 7 items, S9 and S3 showed improvement in 6 items. Of the students showing the least improvement, S2 showed positive changes in 4 items while S8 showed improvement in just one item by reducing his/her act of taking longer gulps. 


\section{Weekly changes occurring in the grammar and spelling dimension in the students}

In the first week, a negative change was observed in the performance of 7 students in some items in the grammar dimension compared to their state in the preliminary interviews. These items were identified to be increasing the number of inverted sentences and short sentences, decreasing the number of long sentences, increasing sentence repetition, answering questions with short answers more and sentence repetitions, making more meaningless pauses during the conversation, expecting more guidance while speaking and reduction in the number of subject predicate relationships established. There are 2 students increasing their use of inverted sentences. There are 4 students increasing the number of short sentences they used and 3 students decreasing the number of long sentences they used. The number of the students who made sentence repetitions more was found to be 4 , the number of the students answering the questions by repeating sentences was found to be 3 , the number of the students who used yes-no short answers more was found to be 2, the number of the students making word repetitions was found to be 1 and the number of the students who expressed regression in establishing subject predicate relationships was found to be 1 . In the second week, 2 of the students did not show any regression in the grammar dimension.

The most common speech mistakes were found to be increasing the number of inverted sentences and short sentences, using more unnecessary words, repeating sentences, giving yes-no short answers to questions, using unnecessary sounds more, and expecting more guidance. There is 1 student who used inverted sentences more, 3 students who used unnecessary words, 3 students who repeated sentences, 3 students who gave short answers, 2 students who made unnecessary sounds, 1 student who used short sentences more often, and 1 student who expected more guidance. In this week, the most mistakes were made in the grammar dimension.

There was a positive change in the grammar dimension in the third week. The items in which regression was observed were identified to be making pointless pauses, making unnecessary sounds, giving yes-no short answers, repeating sentences, increasing the use of short and inverted sentences, and using unnecessary words. In the fourth week, in the grammar dimension, only 2 students expressed regression in one item each compared to the previous application and these items were identified to be expecting more guidance and decreasing the number of longer sentences. In Table 4, the developmental status of the students in speech in terms of the grammar and spelling dimension before and after the application is given.

Table 4. The developmental status of the students in the grammar and spelling dimension

Item

$+\quad$ The child makes long sentences.

The child makes short sentences.

The child makes inverted sentences.

\begin{tabular}{|c|c|c|c|c|c|c|c|c|}
\hline 1 & S2 & 33 & 44 & 5 & S6 & 57 & S8 & 59 \\
\hline & & & & & & & & \\
\hline & $\bar{E} . \bar{a}$ & 莕. & $\bar{J}$ & $\overline{\tilde{J}} \cdot \bar{\Xi}$ & تี & Е & & 0 \\
\hline 7. & $\frac{0}{2}$ & & $\overline{0}$ & 궁 & & & & \\
\hline 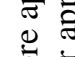 & & & $\begin{array}{l}\pi \\
0\end{array}$ & & & & & $\begin{array}{l}\bar{\sigma} \\
\circlearrowright\end{array}$ \\
\hline 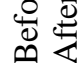 & 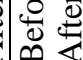 & & 9 & & & & & \\
\hline 5 & 46 & 25 & 25 & 55 & 12 & 33 & 22 & 34 \\
\hline 2 & 21 & 42 & $\begin{array}{ll}5 & 2\end{array}$ & 22 & 64 & $\begin{array}{ll}3 & 4\end{array}$ & 44 & $\begin{array}{ll}3 & 2\end{array}$ \\
\hline 2 & $\begin{array}{ll}2 & 1\end{array}$ & $\begin{array}{ll}3 & 2\end{array}$ & $\begin{array}{ll}5 & 1\end{array}$ & $\begin{array}{ll}1 & 2\end{array}$ & $\begin{array}{ll}3 & 1\end{array}$ & $\begin{array}{ll}2 & 1\end{array}$ & $\begin{array}{ll}3 & 3\end{array}$ & 2 \\
\hline 1 & 22 & 41 & 42 & $\begin{array}{ll}3 & 1\end{array}$ & 42 & $\begin{array}{ll}3 & 1\end{array}$ & $\begin{array}{ll}3 & 3\end{array}$ & 3 \\
\hline 2 & 1 & 2 & 4 & 1 & 2 & $\begin{array}{ll}1 & 2\end{array}$ & 13 & 1 \\
\hline 3 & 2 & 2 & 42 & $\begin{array}{ll}52 \\
5\end{array}$ & $\begin{array}{ll}3 & 3\end{array}$ & 53 & 53 & 2 \\
\hline 4 & 45 & 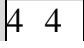 & 4 & 4 & 4 & $\begin{array}{ll}3 & 4\end{array}$ & 43 & \\
\hline
\end{tabular}

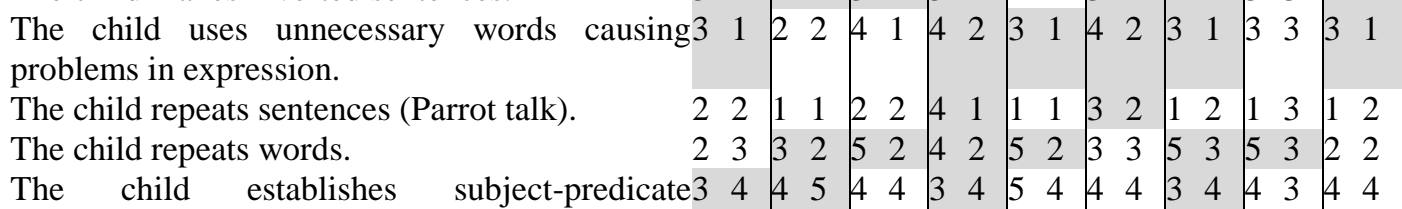


relationships in the sentence.

\begin{tabular}{llllll|ll|ll|ll|llll|lllll} 
The child expects guidance while speaking. & 4 & 1 & 2 & 1 & 4 & 1 & 5 & 1 & 1 & 1 & 5 & 3 & 4 & 1 & 5 & 5 & 2 & 1
\end{tabular}

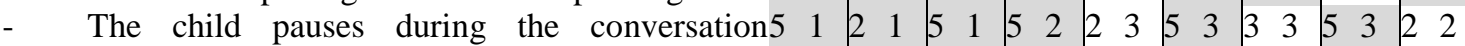

(Pointless pauses).

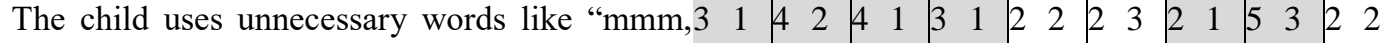
eee, iii."

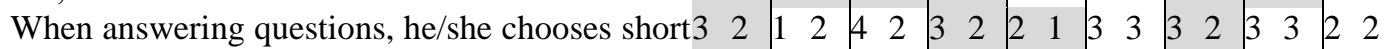
answers with "yes" or "no."

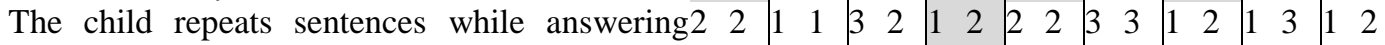
questions.

1-Never 2-Rarely 3-Sometimes 4-Often 5-Usually 6-Always

Negative characteristics related to speaking + Desired characteristics related to speaking

Characteristics developed in speaking

The student who showed the most improvement in the grammar and spelling dimension in the speech, which included 12 items, was S4, who showed positive changes in all the items in the dimension, followed by S1 who showed improvement in a total of 9 items in the grammar and spelling dimension. They are followed by S2 who showed improvement in 8 items and S3 and S6 who showed improvement in 7 items. The students with the least improvement were found to be S5 and S8 who showed improvement in 3 items. In this dimension, most of the students (7 students) made progress in terms of making inverted sentences and expecting guidance while speaking. At the end of the application, the students showed the behaviour of reducing inverted sentences and not being dependent on someone's guidance while speaking.

\section{Weekly changes occurring in the topic dimension in the students}

In the topic dimension, there were generally positive changes in the students for the first week or their performance remained the same as in the preliminary interviews. The items in which regression was observed were identified to be not making a logical introduction to the topic that occurred in 2 students and not making meaningful transitions that occurred in 2 students. One student concluded the topic with an appropriate conclusion sentence. Four students made progress in the topic dimension or their performance remained stable. The changes in the topic dimension for the second week were positive. It was observed that only 1 student experienced regression in terms of making a logical introduction to the topic and meaningful transitions between topics compared to the previous application. For the third week, each student experienced positive changes in the topic dimension. For the fourth week, positive changes were observed in all the students in this dimension. In Table 5, the development status of the students in speech in terms of the topic dimension before and after the application is given.

Table 5. The developmental status of the students in the topic dimension

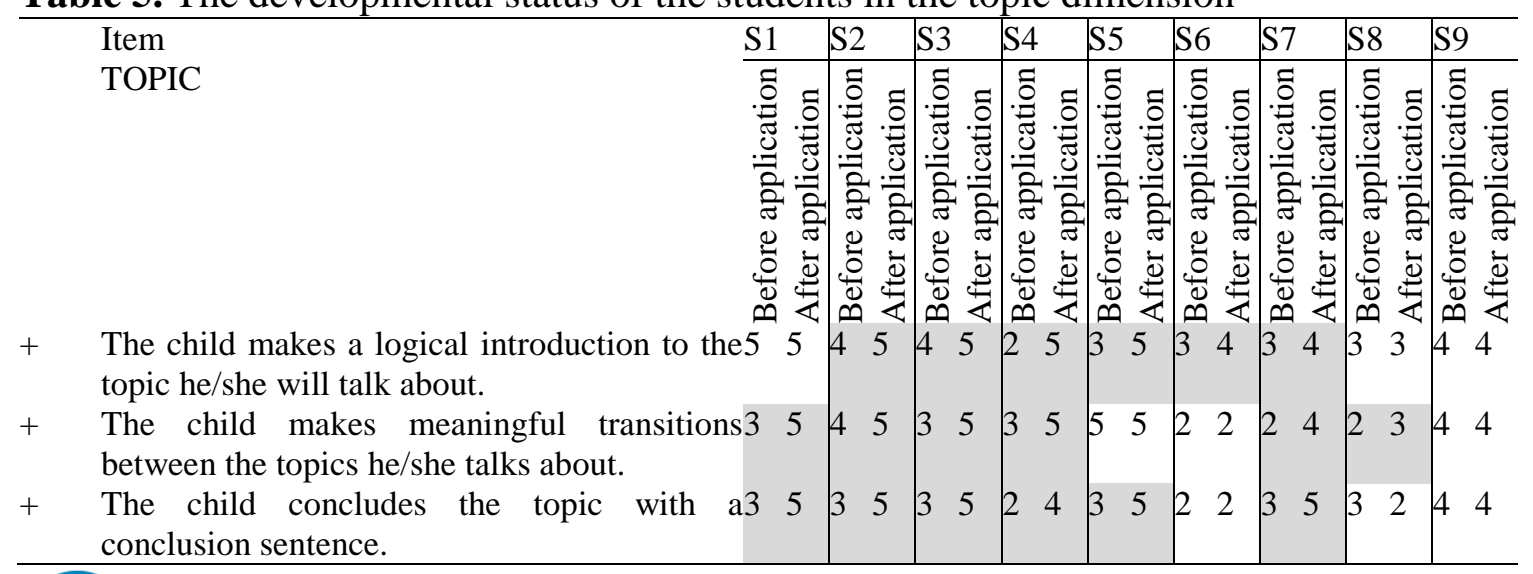


1-Never 2-Rarely 3-Sometimes 4-Often 5-Usually 6-Always

- Negative characteristics related to speaking + Desired characteristics related to speaking Characteristics developed in speaking

A total of 4 students were able to exhibit the best improvement in the topic dimension consisted of 3 items by improving themselves in all the items in this dimension. S2, S3, S4 and S7 demonstrated improvement in all the items in the topic dimension of speech. S1 and S5 showed improvement in 2 items. Of the students who demonstrated the least improvement, S6 showed a positive change in 1 item while $S 9$ showed no change in the topic dimension. In each of the items found in this dimension, 6 students showed improvement. The students showed positive changes in making a logical introduction to the topic, making logical transitions between topics and concluding the topic with a conclusion sentence.

When the 30-item Speech Observation Form was examined in general, the student who showed improvement in the most items (26 items) were identified to be S4. This is followed by S1 (23 items) and S7 (20 items). On the other hand, S8, S9 and S5 were identified to be the students who experienced the fewest changes at the end of the process. While S8 performed positive changes in 8 items, S9 in 11 items and S5 in 15 items. In addition, S9 did not exhibit any positive or negative change in 11 items, S5 in 11 items and S8 in 10 items and they remained stable in terms of the characteristics specified in these items. The reason for this can be that the speech performance of S9 and S5 in the preliminary interviews was relatively better; thus, their speech improvement may have occurred more slowly. On the other hand, it can be said that as S8 had problems paying attention to the lessons and could not express his/her feelings sufficiently because he was a quiet child, he/she may have experienced relatively slower improvement in his/her speech. While this student experienced the highest number of changes in the psychological and grammar and spelling dimensions, he/she showed less positive improvement in the physical and topic dimensions. In addition, the student's failure to attend an application, due to his/her absenteeism caused a gap between the activities.

As a result of the research observations, different characteristics were identified in the speech process of the students from the ones specified in the Speech Disorder Observation Form. Two extra characteristics that can be included in the psychological dimension were identified: behaving comfortably while speaking and increasing self-confidence. The students showed behaviours that could be handled in the dimension of physical characteristics such as speaking by smiling and putting their hands in their pockets, blushing, swaying, lip biting, playing with clothes and paper, not being able to adjust the distance between the paper and the eye, nodding feet and head, grimacing and following what is told with finger. It was determined that local dialects and incorrect pronunciations were also used in the grammar and spelling dimension. In the topic dimension, it was determined that the students' imagination and creativity improved, they paid more attention to details and strengthened their observation skills. In this connection, examples of photos of student behaviours in related videos are given below. 


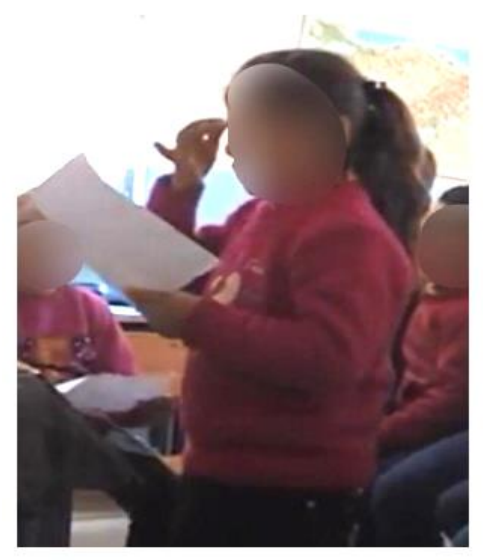

Photo 1. S2's behaviour of playing with her face

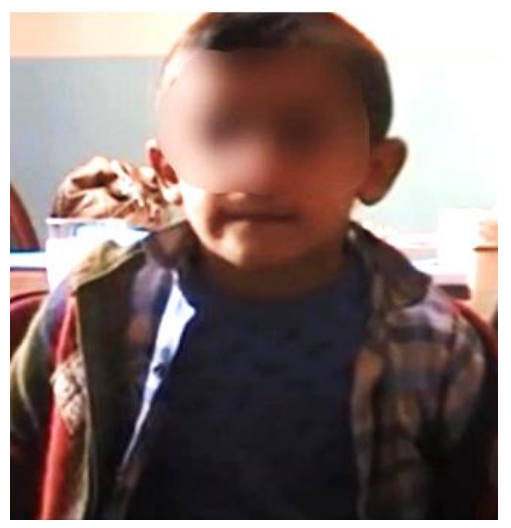

Photo 2. S4's lip biting behaviour

\section{Findings related to Student Opinions}

Data about the students' opinions were obtained through semi-structured interviews conducted after activities to improve speaking skill through cartoons were completed. From the descriptive analysis of the students' responses to the interview questions, the themes shown in Figure 2 were obtained:

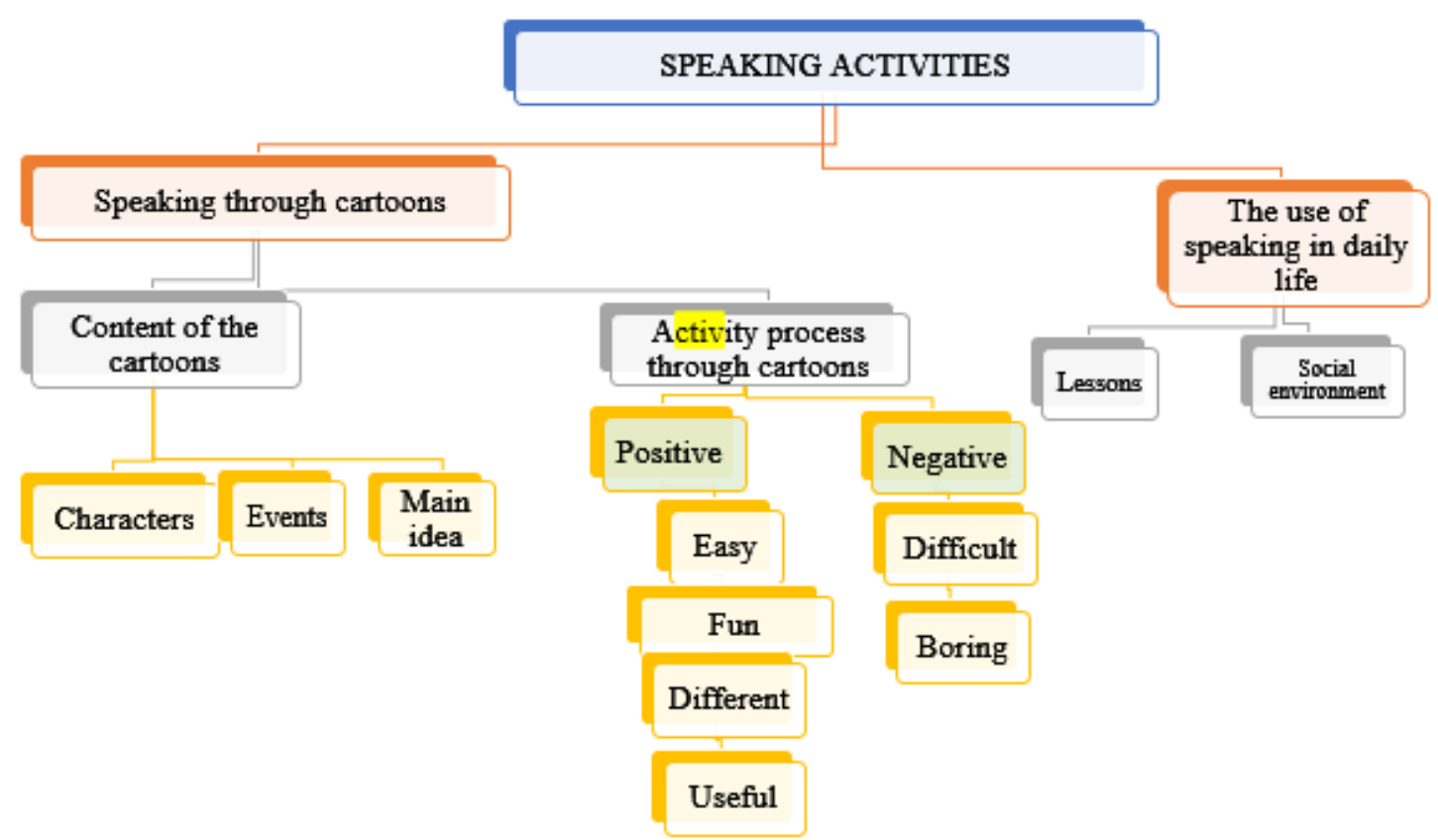

Figure 2. Themes derived from student opinions

Under the main theme of "speaking activities" obtained from student interviews, 2 themes were determined as "speaking through cartoons" and "the use of speaking in daily life". The theme of speaking through cartoons is divided into two categories: the content of the cartoons and the activity process through cartoons. The students expressed positive opinions about the content of the cartoons. When the student responses were examined, it was seen that in every cartoon, the characters were emphasized. In addition, some students explained the cartoons not over the characters but over the events and the main idea and stated that these were the points that attracted their attention. Seven students expressed positive opinions under the 
theme of the activity process through cartoons. However, 2 students expressed negative opinions.

Under the sub-theme of positive, the students described the activities in the Turkish lessons through cartoons as "easy, fun, different and useful". In this connection, one of the students S3 expressed his/her opinions as follows: "It was very nice. I had a lot of fun speaking." and S2: "... we learned many different things ...". Some students evaluated the activities through cartoons negatively because they found them boring and thought that they make speaking difficult. The following can be given as examples to negative opinions: S9: "I had difficulty in some of them. I could not decide what to talk about. I found the picture difficult... I had to think." Within the scope of the theme of the use of speaking in daily life, the students stated that they can use speaking in their daily life, in their lessons and social environments. In this connection, some example student opinions are as follows: S4: "I use it in Turkish lessons." and S9: "I use it at home and school."

\section{Discussion and Results}

As a result of the speaking activities conducted in the current study, positive changes occurred in the speaking skill of the students. It was seen that the students got used to speaking activities at the end of the process, where, it was determined that the students adjusted their voice tones better and the audibility of their voices increased. The students' words become more comprehensible compared the first applications. It was found out that the students' self-confidence increased as the process progressed, and they talked more comfortably in activities. Similarly, Soy (2019) improved the reading skills of the 1st and 2nd grade primary school students taught in a multigrade class by using concept cartoons.

A total of 8 students showed improvement in the psychological dimension of speech. The most positively changed item was the characteristic of looking nervous. A total of 8 students showed improvement in the dimension of physical characteristics of speech. The characteristic in which the students (8) improved the most was found to be adjusting the tone of voice. In addition, the students started to make more eye contact. The least improved item is the students' use of gestures and mimics correctly. Thus, it can be argued that teacher behaviours are effective on students. Özbent's (2007) study supports this finding. Accordingly, it was claimed in the study that a successful body language can be learned professionally.

It was concluded that all of the students showed improvement in terms of the different characteristics in the grammar dimension indicated in the observation form. The characteristics in which most of the students (7) improved were found to be forming inverted sentences and expecting guidance. The characteristics in which the great majority of the students did not show any improvement were found to be the items related to repetition of sentences. The reason for this lack of improvement is thought to be that the application was partially unfamiliar to the students, and their vocabulary was insufficient, and they did not know how to fill the gaps between their words or sentences in their speech. Kuru (2013) found that students started to give short answers with impromptu speech activities and vocabulary development activities and that the number of syllables they used per minute increased. At the end of the research process, it was revealed that the students started to answer the questions by making long sentences. This can be explained by the fact that the students became more sensitive to the events in the cartoons (environmental problems, disabled people,and alike ) and thus actively participated in conversations. Çer (2017) stated 
that cartoons help students to raise awareness about nature, people and life.

According to the results of the topic dimension of the conversation, 6 students showed improvement in some aspects. Three students made progress in speaking in terms of all the characteristics of the topic dimension (viz. making a logical introduction to the topic, making meaningful transitions between topics, and concluding the topic with a conclusion sentence).

Apart from the characteristics indicated in the items in the Speech Disorder Observation Form, different characteristics of the speech emerged from the researcher's observations. It is possible to say that the students' self-confidence increased in the psychological dimension. The reason for this situation can be that increased repetition and continuity with cartoons reduced the students' anxiety levels.

In relation to self-confidence, Haugaard (1973) stated that cartoons increased students' motivation to express their thoughts and thusly fostered their self-confidence. In the physical dimension, it was revealed that the emotional reactions of the students when they were nervous reflected on their physical behaviours except for smiling and talking with their hands in their pockets. These physical characteristics include blushing, lip biting, swaying, playing with clothes and paper. In addition, in terms of physical dimension, it was revealed that the students talked by shaking their feet and head, grimacing, following with finger and emphasizing the points they told. As a result of the study, it was revealed that face blushing and lip biting behaviours decreased in direct proportion to the decrease in anxiety of the students and that the students started to adjust the distance between the paper and the eye more accurately.

Among the topics that emerged as a result of the researcher's observations and those that were associated with the dimension of grammar and spelling, the most common behaviour was found to be students' using the local dialect. This situation in the speech continued throughout the research process. This may be due to students' continuing the speaking style at home and not receiving appropriate feedback for mistakes they made in speaking. Similar findings were also reported by Eryılmaz (2015), Doğan (2009) and Temizyürek (2007) in their studies. In line with the observations of the researcher, other characteristics that emerged in the topic dimension of the study were imagination and creativity. It was concluded that the imagination and creativity of the students participating in the study improved. Çer (2017) stated that students use their creativity through cartoons. Ersoy and Türkkan (2010), on the other hand, reached the conclusion in their study that the creativity of primary school students improved as a result of their speaking about the cartoons they drew themselves.

As a result of the semi-structured interviews carried out with the students in the study, it was concluded that the students generally had positive opinions about the applications. At the end of the study, several opinions about the content of the cartoons and the activity process emerged. The cartoons were handled by the students mostly in terms of characters, events and main idea. In the study, it was concluded that the part found to be the most interesting by the students in the cartoons is the characters. However, it was revealed that the students had difficulty determining the main idea. Here it would be fair to state that this is due to the fact that the cartoons are abstract for the students; therefore, the students could not fully grasp the main idea and did not have a clear idea about it. In addition, the study revealed that when asked about the main idea of the cartoon, the students could not give the correct answer, instead they talked about the characters and events in the cartoon. In this connection, in the study of Çetinkaya, Ateş \& Yıldırım (2013), it was concluded that primary school 5th grade 
students were largely unsuccessful in determining the main idea. It was revealed that most of the students (7) found the cartoon activities fun, easy, different and useful, and 2 students found the cartoon activities difficult and boring. Students who said that they found the activities boring related the reason for this to the difficulty of the activities. It can be said that the students found the activities difficult as the cartoons are abstract and the students have different interests and attention spans. Çer (2017) stated that teachers should choose artistic cartoons suitable for the level of their students in classroom activities and emphasized the importance of using different cartoons in terms of the educational process. Similarly, Demiralp (2007) and Yalın (2002) stated in their studies that the material chosen in the educational and instructional process should be suitable for the grade level.

On the basis of the students' opinions about the use of cartoons in daily life, it was revealed that they could use cartoons in lessons and in their social environment. However, students stated that they could not use these activities in other lessons, as they were used in Turkish lessons. The opinion of the students that they can only use cartoons in Turkish lessons may be due to their inability to associate speaking skill with other lessons since the research was conducted within the scope of the Turkish course. This shows that speaking education is a process that should be handled within the context of each course. Two students stated that they can use the cartoons outside the school at home and anywhere. This view was not addressed under the home sub-theme but was classified under the heading entitled 'social environment'. In making this classification, the observations of the researcher, the contexts and the living habits of the students in their environment were taken into consideration. Although the lives of students outside the school are limited to home, it was deemed appropriate to call the outer social area they expressed as simply anywhere. This finding of the current study concurs with the result of Ersoy \& Türkkan (2010) that the culture that students are in has an important effect while interpreting societal problems. Kol (2011) stated that, from an early age, the family and school environment in which the child lives contributes to the healthy completion of his/her cognitive and language development. Kleeman (2006) stated that students reveal their own value systems by drawing cartoons on the social or environmental situations. In addition, Eulie (1969) concluded that cartoons enable students to think about current events, social and family environments, values in society and moral situations. In line with the opinions of the students, it was revealed that the cartoons constitute material that can be used in different courses. To this very end, studies conducted in science teaching (Keogh \& Naylor, 1999; Stephenson \& Warwick, 2002) revealed that students expressed positive opinions regarding the use of concept cartoons and that cartoons improved students' inquiry skills. Similarly, Clary \& Wandersee (2010) discussed using scientific cartoons as an alternative assessment for science learning, and it was revealed that students were satisfied with being evaluated through cartoons. In this context, it can be said that classroom activities with different types of cartoons can be useful for students of all ages and will improve the learning-teaching process.

In order to improve speaking skill, it may be suggested to use different materials other than cartoons and apply them in different courses. In addition, during the current study, it was observed that the students imitated their teachers' speech and took them as their role models. Considering this situation, applied diction training can be added to teacher training programs for pre-service teachers who will be role models to their students whilst educating their students for them to speak better and express themselves in a better manner. 


\section{Note}

The current article was produced from a master's thesis prepared in the Institute of Educational Sciences at Muğla Sitkı Koçman University.

\section{References}

Akengin, H. \& İbrahimoğlu, Z. (2010). Sosyal bilgiler dersinde karikatür kullanımının öğrencilerin akademik başarısına ve derse ilişkin görüşlerine etkisi [Effects of use of cartoons in social studies course on students' academic achievement and their opinions about the course]. Ondokuz Mayls University Journal of Faculty of Education, 29(2), 1-19. Retrieved from http://www.acarindex.com/dosyalar/makale/acarindex-1423910316.pdf

Akgül, F. (2019). Karikatür (çizgi roman) yoluyla yabancı dil ögrretimi [Foreign language teaching through comics]. (Unpublished master's thesis), Atatürk University, Erzurum, Turkey.

Akkaya, A. (2011). Karikatürlerle dil bilgisi ögretimi [Teaching grammar with cartoons]. (Unpublished doctoral dissertation), Selçuk University, Konya, Turkey.

Akyol, H. (2011). Türkçe ögretim yöntemleri [Methods of Turkish teaching]. Ankara: Pegem Akademi.

Bashir, M., Azeem, M., \& Dogar, A. H. (2011). Factor effecting students' English speaking skills. British Journal of Arts and Social Sciences, 2(1), 34-50, Retrieved from https://www.researchgate.net/publication/228840274_Factor_Effecting_Students'_Eng lish_Speaking_Skills

Bayülgen, N. (2011). Yazı çalışmalarında karikatür, motivasyon ve yaratıcılık [Cartoons, motivation and creativity in writing]. Journal of Inquiry Based Activities, 1(1), 39-55. Retrieved from https://ated.info.tr/index. php/ated/article/view/4

Boonkit, K. (2010). Enhancing the development of speaking skills for non-native speakers of English. Procedia Social and Behavioral Sciences, 2(2), 1305-1309. https://doi.org/10.1016/j.sbspro.2010.03.191

Clary, R. M., \& Wandersee, J. J. (2010). Scientific caricatures in the earth science classroom: An alternative assessment for meaningful science learning. Sci \& Educ, 27, 19-21. https://doi.org/10.1007/s11191-008-9178-y

Çer, E. (2017). Karikatürlerle Türkçe ögretimi [ Teaching Turkish with cartoons]. Ankara: Eğiten Kitap Yayınevi.

Çetinkaya, Ç., Ateş, S. \& Yıldırım, K. (2013). Anlam kurmanin zor ve önemli bir becerisi: Ana fikri bulma [Difficult and curial skill in making meaning: Finding main idea]. Journal of Theory and Practice in Education, 9(3), 188-210. Retrieved from http://acikerisim.lib.comu.edu.tr:8080/xmlui/handle/COMU/1172

Demir, T. (2010). Konuşma eğitiminde benmerkezci konuşmaya yönelik bir deneme [An essay for egocentric speaking in speech education]. Kastamonu Education Journal, $18(2), 4135-430$.

Demiralp, N. (2007). Coğrafya eğitiminde materyaller ve 2005 coğrafya dersi öğretim program1 [Materials in geography education and the geography curriculum 2005]. Kastamonu Education Journal, 15(1), 373-384. Retrieved from https://dergipark.org.tr/en/download/article-file/819275

Demirel, Ö. \& Şahinel, M. (2006). Türkçe ve sınıf ögretmenleri için Türkçe ögretimi [Teaching Turkish for Turkish teachers and primary school teachers]. Ankara: Pegem Yayıncilik. 
Doğan, Y. (2009). Konuşma becerisinin geliştirilmesine yönelik etkinlik önerileri [Suggested activities to improve speaking skill]. The Journal of Turkish Educational Sciences, 7(1), 185-204. Retrieved from https://dergipark.org.tr/tr/download/article-file/256509

Dönmez, A. (2013). İlkögretim 7. sinıf öğrencilerinin Türkçe ögrretiminde okuduğunu anlama ve yazma becerilerinin gelişmesinde karikatürün etkisi [The effect of the cartoons on reading comprehension and developing writing skills in Turkish teaching of 7th students in elementary education]. (Unpublished master's thesis), Abant İzzet Baysal University, Bolu, Turkey.

Erdem, İ. \& Deniz, K. (2008). Güzel konuşma kurslarında verimliliği artırmaya yönelik bir alan araştırması [A scope research on related to improve prolificness in eloquence courses]. Mustafa Kemal University Journal Social Sciences Institute, 5(10), 75- 90.

Ersoy, A. F. \& Türkkan, B. (2010). İlköğretim öğrencilerinin çizdikleri karikatürlere yansıttıkları sosyal ve çevresel sorunların incelenmesi [Analyzing social and environmental issues elementary school students reflect in their cartoons]. Education and Science, 35 (156), 96-109. Retrieved from http://egitimvebilim.ted.org.tr/index.php/EB/article/view/119/

Eryılmaz, R. (2015). Çameli ilçesi ă̆zl ve Çameli ortaokullarında ĕgitim gören öğrencilerin yerel ă̆ız özelliklerinin Türkçe eğitimine etkisi [The accent in Çameli district and the effect of accent features of the students who has been studied at the secondary schools in Çameli to Turkish language teaching]. (Unpublished master's thesis), Pamukkale University, Denizli, Turkey.

Eulie, J. (1969). Creating interest and developing understanding in social studies through cartoons. Peabody Journal of Education, 46(5), 288-290.

Guba, E. G. (1981). Criteria for assessing the trustworthiness of naturalistic inquiries. ECTJ, 29(2), 75-91.

Haugaard, K. (1973). Comic books: Conduits to culture. Reading Teacher, 27, 54-55. Retrieved

from https://www.jstor.org/stable/pdf/20193391.pdf?refreqid=excelsior\%3Ac7e6c61c5112e $2769 \mathrm{c} 005 \mathrm{c} 7 \mathrm{~b} 85 \mathrm{dff} 581$

Johnson, A. P. (2005). A short guide to action research. Pearson/Allyn and Bacon.

Keogh, B., \& Naylor, S. (1999). Concept cartoons, teaching and learning in science: An evaluation. International Journal of Science Education, 21(4), 431-446. doi:10.1080/095006999290642

Kleeman, G. (2006). Not just for fun: Using cartoons to investigate geographical issue. Ethos, 14(3), 9-19.

Koçoğlu, E. (2012). 6. sınıf sosyal bilgiler dersinde karikatür kullanımının erişiye göre değerlendirmesi [6th grade social studies lessons according to criteria evaluation of the use of cartoon]. (Unpublished doctoral dissertation), Atatürk University, Erzurum, Turkey.

Kol, S. (2011). Erken çocuklukta bilişsel gelişim ve dil gelişimi [Cognitive development and language development in early childhood]. Sakarya University Journal of Education, 375, 1-21, Retrieved from https://dergipark.org.tr/tr/download/article-file/115636

Köksal, K. (2002). Birleştirilmişs sınıflarda öğretim [Teaching in multigrade class]. Ankara: PegemA Yayıncilık.

Kuru, O. (2013). Akıcı konuşma problemi yaşayan ilkokul 4. sınıf ögrencilerinin konuşma becerilerinin geliştirilmesi [Improving the speaking skills of elementary 4th grade students with speaking fluency problems]. (Unpublished doctoral dissertation), Gazi University, Ankara, Turkey. 
Kurudayığlu, M. (2003). Konuşma eğitimi ve konuşma becerisini geliştirmeye yönelik etkinlikler [Speaking education and activities to improve speaking skills]. Journal of Turkology Research, 13, 287-309. Retrieved from https://dergipark.org.tr/tr/download/article-file/156773

Little, A. W. (2001). Multigrade teaching: towards an international research and policy agenda. International Journal of Educational Development, 21, 481-497.

Oban, R. (2017). The importance of using cartoon in geography teaching: An example of Turkey's natural heritage course. The Journal of Academic Social Sciences, 46(5), 2238. Retrieved

from https://asosjournal.com/?mod=tammetin\&makaleadi=\&makaleurl=67255196_12202\% 20Raziye \%20\%C3\%87AKICIO\%C4\%9ELU\%20OBAN.pdf\&key=34468

Oradee, T. (2012). Developing speaking skills using three communicative activities (discussion, problem-solving and role playing). International Journal of Social Science and Humanity, 2(6), 533-535. doi: 10.7763/IJSSH.2012.V2.164

Orhan, H. (2018). Ortaokul öğrencilerinin çevre sorunları algllarının karikatür yoluyla belirlenmesi [Determination of the perceives of the environmental problems of the secondary school students through the cartoon]. (Unpublished master's thesis), Niğde Ömer Halisdemir University, Niğde, Turkey.

Örs, F. (2005). Karikatürler, rastgele değil, uzman eğitimciler tarafindan titizlikle ve bilinçli bir şekilde seçilmelidir [Cartoons should be carefully and deliberately selected by expert educators, not randomly]. Hürriyet Gösteri Sanat ve Edebiyat Dergisi, 275(80).

Özbent, S. (2007). Sinifta beden dili [Body language in the classroom]. Gazi University Journal of Gazi Educational Faculty, 2(27), 259-289, Retrieved from http://www.gefad.gazi.edu.tr/tr/download/article-file/77157

Patton, M. Q. (2002). Qualitative research and evaluation methods. (3rd edition). Sage Publications.

Perkins, D. (1975). A definition of caricature and caricature and recognition, Studies in Visual Communication, 2(1), 1-24.

Sever, S. (2011). Sözlü anlatım: Konuşma. In Ş. D. Belet (Ed.), Türkçe sözlü anlatım [Turkish verbal expression] (109-131), Eskişehir: T.C Anadolu Üniversitesi.

Sever, S. (1993). Türkçe öğretiminde uygulanan tam ögrenme kuramı ilkelerinin, ögrencilerin okuduğunu anlama ve yazll anlatım becerilerindeki erişiye etkisi [The effect of the principles of full learning theory applied in Turkish teaching on students' reading comprehension and written expression skills]. (Unpublished doctoral dissertation), Ankara University, Ankara, Turkey.

Soy, O. (2019). Kavram karikatürleri aracılı̆̆lyla ilkokul 1. ve 2. sinıf öğrencilerinin okumayazma becerilerinin geliştirilmesi [The development of reading-writing skills of the 1st and 2nd grade students with the concept cartoon]. (Unpublished master's thesis), Muğla Sitkı Koçman University, Muğla, Turkey.

Stephenson, P., \& Warwick, P. (2002). Using concept cartoons to support progression in students understanding of light. Physics Education, 37(2), 135-141. doi: 10.1088/0031-9120/37/2/306.

Şahan, H. (2009). Yazın ve karikatür [Literature and cartoon]. İzmir: İlya Yayınevi.

Şenocak, K. Z. (2018). Fen ögretiminde kavram karikatürü kullanımının 5. sınıf yaşamımızdaki elektrik ünitesinde öğrenci başarısı ve tutumu üzerine etkileri [The effects of using concept cartoons in science teaching on the student attitudes and their academic performances in the 5th grade unit called 'Electricity in our lives"]. (Unpublished master's thesis), Kırıkkale University, Kırıkkale, Turkey. 
Temizkan, M. (2009). Akran değerlendirmenin konuşma becerisinin geliştirilmesi üzerindeki etkisi [The effect of peer assessment on the development of speaking skill]. Mustafa Kemal University Journal Social Sciences Institute, 6(12), 90-11. Retrieved from https://openaccess.mku.edu.tr/xmlui/bitstream/handle/20.500.12483/1271/Temizkan\% 2cMehmet2009.pdf? sequence=1\&isAllowed=y

Temizyürek, F. (2007). İlköğretim ikinci kademede konuşma becerisinin geliştirilmesi [Progressing speaking ability in second level of elementary education]. Ankara University Journal of Faculty of Educational Sciences, 40(2), 113-131. Retrieved from https://dergipark.org.tr/tr/download/article-file/509055

Tomal, D. R. (2010). Action research for educators. [Electronic version]. New York: Rowman \& Littlefield Publishers.

Tompkins, G. E. (1998). Language arts content and teaching strategies. New Jersey: California State University Prentice Hall Inc.

Tsou, W. (2005). Improving speaking skills through instruction in oral classroom participation. Foreign Language Annals, 38(1), 46-55. Retrieved from https://onlinelibrary.wiley.com/doi/epdf/10.1111/j.1944-9720.2005.tb02452.x

Üner, İ. (2009). İlköğretim okullarında karikatürle ögrenmenin öğrencilerin başarı ve tutum düzeylerine etkisi [The effects of learning via cartoons on students? success and attitude levels in primary schools]. (Unpublished master's thesis), Marmara University, İstanbul, Turkey.

Yalın, H. İ. (2002). Öğretim teknolojileri ve materyal geliştirme [Instructional technologies and material development]. Ankara: Nobel Yayınları.

Yıldırım, A. \& Şimşek, H. (2018). Sosyal bilimlerde nitel araştırma yöntemleri [Qualitative research methods in the social sciences]. Ankara: Seçkin Yayıncılık. 